\title{
How could the bushmeat trade in the Kilombero Valley of Tanzania be regulated? Insights from the rural value chain
}

\author{
Martin Reinhardt Nielsen, Henrik Meilby and Carsten Smith-Hall
}

\begin{abstract}
Bushmeat trade is a threat to biodiversity in Africa. Information about the bushmeat value chain can inform conservation policies, yet such knowledge is lacking for most of East Africa. We examine the structure and organization of bushmeat markets in three villages in the Kilombero Valley of Tanzania, where illegal hunting is widespread. We base our analysis on 1,855 observations of trade during 1 year (2008-2009) and questionnaire interviews with 325 individuals involved in the trade in 2011. Our results reveal that the trade is large-scale both in volume (1,100 animals, equivalent to $370,000 \mathrm{~kg}$ meat per year) and local turnover (USD 210,000 per year) and that several threatened species are hunted. There are no patron-client relationships and hunters, traders and retailers, which are the main actors involved, conduct only basic product upgrading (drying and making packages). The value chain is characterized by governance problems, including widespread rent-seeking and violent enforcement. Although hunting is open-access, lack of access to firearms constitutes an entry barrier, curbing supply and enabling actors to realize supernormal profits. Decentralization of management rights and responsibilities to communities, supplemented by improved firearms control, appears the most realistic option for regulating the trade and preventing further declines of wildlife.
\end{abstract}

Keywords Bio-economic equilibrium, bushmeat, commodity chain, East Africa, illegal hunting, market

\section{Introduction}

T unting of wildlife for food and income (bushmeat - hunting) is considered a major threat to biodiversity (Robinson \& Bennett, 2000; Milner-Gulland et al., 2003) and the bushmeat trade has the potential to rapidly deplete wildlife populations (Robinson \& Bennett, 2000; Bennett et al., 2007). Regulating this trade effectively is therefore a

Martin Reinhardt Nielsen* (Corresponding author), Henrik Meilby and CARSTEN SMITH-Hall Department of Food and Resource Economics, University of Copenhagen, Rolighedsvej 23, DK-1958 FRB C., Denmark

E-mail mrni@ifro.ku.dk

*Also at: Centre for Macroecology, Evolution and Climate, Universitetsparken 15, University of Copenhagen, DK-2100 KBH Ø, Denmark

Received 28 June 2013. Revision requested 8 October 2013.

Accepted 29 January 2014. First published online 22 July 2014. key conservation challenge. The quantity of bushmeat demanded and supplied depends on the interaction between price, consumer incomes and the price of substitute goods (Milner-Gulland, 2001). Regulation efforts can attempt to influence demand or supply. Available evidence from the demand side is ambiguous (Fa et al., 2009; Godoy et al., 2010) and resulting management recommendations, such as increasing the wealth of rural consumers and/or providing sufficient amounts of cheap substitute meat, appear unrealistic in the short to medium term (Fa et al., 2003; Rowcliffe et al., 2005; Fa \& Brown, 2009). Influencing supply is easier in practice because of the lower number of suppliers. Interventions include enhanced law enforcement and providing hunters with alternative sources of income (Nielsen et al., 2014), which theoretically will increase supply costs, through fines and the opportunity costs of hunting (Milner-Gulland, 2001). However, market structure and efficiency are also important to consider when planning interventions (Cowlishaw et al., 2005; de Merode \& Cowlishaw, 2006; Morra et al., 2009). Markets in developing countries are often imperfect in terms of distribution of information, bargaining power and access to credit (Ellis, 1992; Pokhrel \& Thapa, 2007). Markets for illegal products may also be based on informal agreements or patron-client relationships with enforcement agents or authority representatives to facilitate circumvention of wildlife management regulations (de Merode \& Cowlishaw, 2006).

The majority of studies of bushmeat markets in Africa have been conducted in West and Central Africa, whereas research on the bushmeat trade in East Africa is limited. This geographical asymmetry appears to be caused by differences in law enforcement. Although the bushmeat trade in most aspects is illegal in West, Central and East Africa, enforcement of wildlife regulations is stricter in East Africa. The bushmeat trade therefore occurs clandestinely in Tanzania, Kenya and Uganda, making it more difficult to study compared to countries where it occurs openly in marketplaces. We reduced the sensitivity of the issue by using local field assistants, establishing long-term relations and guaranteeing anonymity to the participants in the bushmeat markets in three villages in the Kilombero Valley of south-central Tanzania. Our aims were to increase our understanding of (1) the structure and organization of bushmeat markets in East Africa, including horizontal and vertical elements of the value chain, and (2) the implications of this for wildlife conservation efforts in Tanzania. 


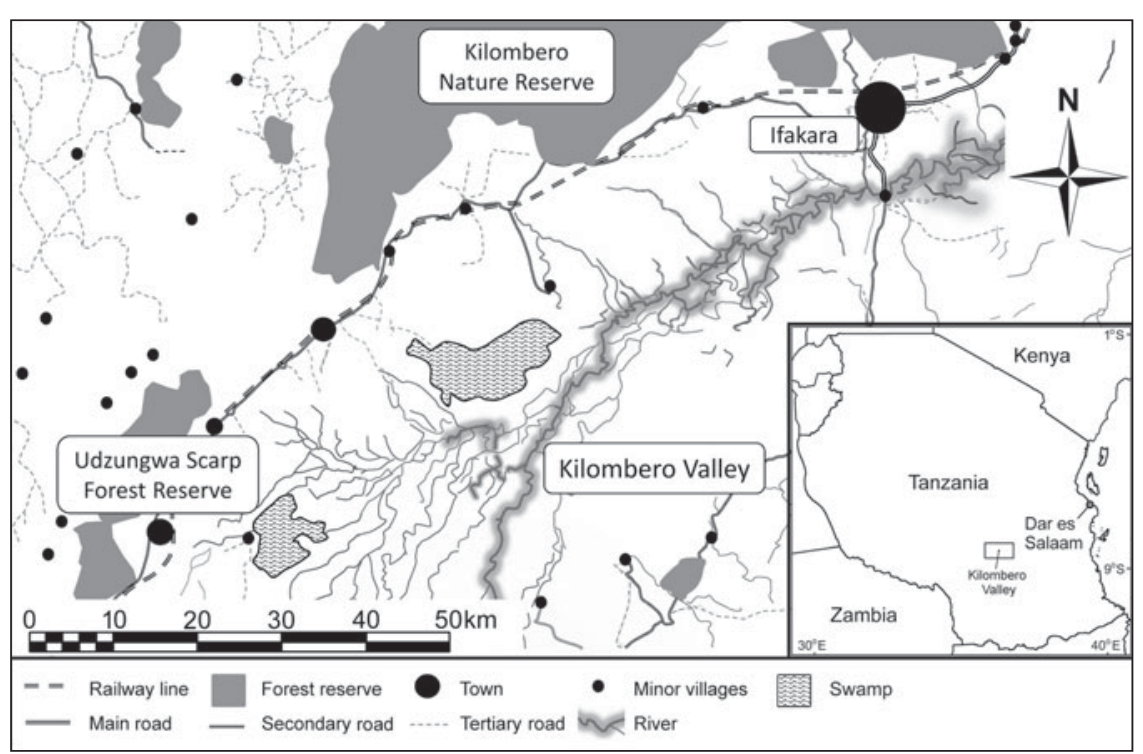

FIg. 1 The Kilombero Valley. The rectangle on the inset shows the location of the main map in Tanzania.

\section{Study area}

The Kilombero Valley $\left(>6,550 \mathrm{~km}^{2}\right)$ is one of Africa's largest wetlands and is part of the greater Selous-Niassa ecosystem, centred on the world heritage-listed Selous Game Reserve to the south (Fig. 1). To the north are the Udzungwa Mountains of the Eastern Afromontane Biodiversity Hotspot and to the north-east the Mikumi National Park. Administratively, the valley falls within the Kilombero and Ulanga Districts in Morogoro Region, c. $320 \mathrm{~km}$ west of Dar es Salaam.

The Kilombero Valley holds $75 \%$ of the global population of puku Kobus vardonii, which is believed to be declining in most of its range and is categorized as Near Threatened on the IUCN Red List (IUCN SSC Antelope Specialist Group, 2009), and the species' survival is thus dependent on this site (Jenkins et al., 2002). The Kilombero Valley is designated as a Game Controlled Area and divided into two hunting blocks. Unlicensed hunting is prohibited but widespread and is considered the main cause of decline of several species, including puku (Bonnington et al., 2010).

Here we focus on three villages that were known to have bushmeat trade. The villages, which are anonymized to protect the informants in this study, are located between the Game Controlled Area and the Udzungwa Mountains. Village natural resource councils and environmental committees, under the village councils and aided by village game scouts, both conduct patrols to deter and arrest illegal hunters and bushmeat traders. Wildlife Division scouts and foresters of the District Lands and Natural Resources Office occasionally conduct patrols in the Game Controlled Area and the Udzungwa Scarp Forest Reserve, respectively. Tanzania National Parks also has a ranger post in the area.

\section{Methods}

We applied a value chain approach (Mitchell \& Coles, 2011) focused on the harvesting, processing, transport, distribution and sale of bushmeat in the three villages. Data collection was limited to (1) bushmeat, excluding highvalue complementary products; (2) a village-based survey, with no attempt to participate in hunting trips; and (3) the local trade, with no attempt to interview higher level actors along the value chain to urban centres. These delimitations were necessary for the security of research staff and facilitated investigation of the local origin of the bushmeat trade by avoiding more sensitive issues such as ivory trade.

\section{Data collection}

The study was facilitated by MRN's interaction with participants in the bushmeat trade during 2008-2011, and the use of local field assistants ensured respondents' trust, collaboration and open discussion on the subject. Data were collected through a market survey, opportunistic informal conversations and structured interviews. The market survey was conducted 5 days per week during July 2008-October 2009 by one local assistant in each village, initially posing as a customer or as someone interested in joining the trade. All individuals selling bushmeat were approached and information was obtained through informal interviews and by observing transactions. Data included origin (i.e. Kilombero Game Controlled Area or Udzungwa Scarp Forest Reserve) and species of meat sold, age of the animal (young or adult), state of the meat (fresh or dried), and the price negotiated. Data from the first 2 months were excluded as this time was spent establishing good rapport with traders, 
facilitating data collection and species identification through inspection of body parts in traders' households. In total 1,855 informal interviews were conducted in the market survey.

Additional information was collected through opportunistic conversations with individuals involved in the trade. Data included method of hunting, origin of weapons and ammunition, means of transport to other villages and towns, interaction with authorities and enforcement staff, and the structure of the value chain. Field notes were written after conversations and the narratives were validated by triangulation between informers from different villages. This information enabled us to define three main actor groups involved in the local bushmeat value chain: hunters, traders and retailers.

Structured interviews were conducted in October and November 2011, using snowball sampling (Patton, 1990) to identify all individuals involved in the bushmeat trade. All respondents were guaranteed anonymity at both the village and household levels. Data collected included (1) basic demographic and socio-economic data on household composition, education, assets and income from sources other than the bushmeat trade, (2) information on involvement (i.e. function) in the trade, (3) number and duration of hunting trips or time spent trading bushmeat during the past month and year (specific to each actor group), and (4) cost and gross income from the latest hunting trip or day spent trading bushmeat. Finally, we collected detailed descriptions of situations where respondents had been apprehended hunting or trading bushmeat. Respondents included 80 hunters, 169 traders and 76 retailers, grouped according to their own descriptions of their function in the bushmeat trade. Individuals outside the local value chain and those in prison or injured at the time of the study were excluded.

\section{Data analysis}

Bushmeat is brought into villages at night and sold the following morning in packages (kipande) weighing c. $2 \mathrm{~kg}$. This makes it impossible to trace individual animals along the value chain and complicates calculation of total harvest. Hence, we provide a conservative estimate of (1) the number of animals traded locally and (2) the total number of animals killed during the study year (with the difference between these two figures representing the amount consumed in the households of hunters and traders or traded non-locally), using an approach inspired by methods developed to estimate the number of animals poached from seized ivory, skin, bones and other wildlife products (Parker \& Martin, 1982; Stoner \& Pervushina, 2013). The number of animals traded locally in each village was estimated based on the number of packages in the possession of individual traders/ retailers at the beginning of each day, divided by the number of packages produced from slaughtering each relevant species (taking into consideration young and adult specimens, normal days and public holidays). Observations from subsequent days when the same individual sold meat from the same species, up to 3 and 7 consecutive days for fresh and dried meat, respectively, were omitted to avoid double counting. The total number of animals killed was estimated by assuming that each record of a species traded in the market represented one animal, omitting observations of the same species traded by more than one individual in the same village on the same day and observations of trade of the same species from consecutive days (as above). Hence, a combined stock of 45 packages of fresh buffalo Syncerus caffer meat from an adult individual for all traders in a given village, at the beginning of the day, indicates that a quarter of a buffalo was traded locally. But it also means that at least one buffalo was killed, suggesting that the remaining proportion was either consumed in the households of hunters and traders or, more likely, transported to non-local markets. We extrapolated from mean monthly villagespecific kills per day to cover non-surveyed days. Biomass was estimated by multiplying the number of animals killed by published mean species weights ( $\mathrm{Fa} \&$ Purvis, 1997). If this information was unavailable we used median adult weight ranges, according to Kingdon (1997). The amount of edible meat produced was calculated by subtracting the inedible proportion (35\%), according to Hill \& Hawkes (1983). Market values were estimated based on these figures and the species-specific prices for packages and whole animals. Prices in 2008 and 2009 were converted to 2011 values by correcting for inflation, using World Bank consumer price index values (The World Bank, 2012). All household income figures were converted to adult equivalent units, following Cavendish (2002). Profit was calculated from income and costs of the most recent hunting trip or days trading bushmeat and converted to profit per day and per month, based on the number and duration of hunting trips and trading days in the past month. We compared socio-demographic parameters between actor groups, using standard descriptive statistics in STATA v. 11.2 (StataCorp, College Station, USA).

We analysed value chain governance issues, with emphasis on strategies and mechanisms (debts, agreements, allegiances, bribes) used by actor groups to secure their own or restrict others' access to the market. Here, governance is narrowly understood as the process of exercising control along the chain (i.e. who influences production, transport, distribution and sale of bushmeat, and how). Particular attention was focused on investigating relations with authorities and enforcement staff, based on data describing actual apprehensions. This allowed us to estimate the likelihood of various outcomes, depending on the enforcing authority. 
TABLE 1 Estimated numbers of animals traded locally and animals killed for hunters' own consumption or non-local trade, in three villages in the Kilombero Valley, Tanzania (Fig. 1), during September 2008-August 2009.

\begin{tabular}{|c|c|c|c|c|c|c|c|c|c|}
\hline & \multicolumn{3}{|c|}{$\begin{array}{l}\text { No. of animals traded } \\
\text { locally }\end{array}$} & \multicolumn{3}{|c|}{$\begin{array}{l}\text { No. of animals killed for } \\
\text { own consumption \& non- } \\
\text { local trade }\end{array}$} & \multicolumn{3}{|c|}{ Total kill } \\
\hline & Fresh & Dry & Total & Fresh & Dry & Total & Fresh & Dry & Total \\
\hline Yellow baboon Papio cynocephalus & 0 & 0 & 0 & 1 & 0 & 1 & 1 & 0 & 1 \\
\hline Crested porcupine Hystrix cristata & 0 & 0 & 0 & 3 & 2 & 5 & 3 & 2 & 5 \\
\hline Cane rat Thryonomys spp. & 4 & 1 & 5 & 51 & 2 & 53 & 55 & 3 & 58 \\
\hline Genet Genetta spp. & 0 & 0 & 0 & 1 & 0 & 1 & 1 & 0 & 1 \\
\hline African civet Civettictis civetta & 0 & 0 & 0 & 3 & 0 & 3 & 3 & 0 & 3 \\
\hline Bush cat Felis silvestris & 0 & 0 & 0 & 0 & 1 & 1 & 0 & 1 & 1 \\
\hline Hyrax (Hyracoidea spp.) & 3 & 2 & 5 & 69 & 6 & 75 & 72 & 8 & 80 \\
\hline African elephant Loxodonta africana & 1 & 11 & 12 & 5 & 2 & 7 & 6 & 13 & 19 \\
\hline Hippopotamus Hippopotamus amphibius & 20 & 60 & 80 & 97 & 28 & 125 & 117 & 88 & 205 \\
\hline Bushpig Potamochoerus larvatus & 20 & 11 & 31 & 89 & 47 & 136 & 109 & 58 & 167 \\
\hline Warthog Phacochoerus africanus & 5 & 2 & 7 & 23 & 9 & 32 & 28 & 11 & 39 \\
\hline African buffalo Syncerus caffer & 31 & 46 & 77 & 90 & 27 & 117 & 121 & 73 & 194 \\
\hline Bushbuck Tragelaphus scriptus & 4 & 4 & 8 & 32 & 18 & 50 & 36 & 22 & 58 \\
\hline Blue duiker Cephalophus monticola & 2 & 4 & 6 & 23 & 14 & 37 & 25 & 18 & 43 \\
\hline Harvey's duiker Cephalophus harveyi & 2 & 2 & 4 & 3 & 0 & 3 & 5 & 2 & 7 \\
\hline Abbott's duiker Cephalophus spadix & 1 & 1 & 2 & 2 & 4 & 6 & 3 & 5 & 8 \\
\hline Duiker Cephalophus spp. & 4 & 1 & 5 & 23 & 0 & 23 & 27 & 1 & 28 \\
\hline Puku Kobus vardonii & 57 & 3 & 60 & 146 & 6 & 152 & 203 & 9 & 212 \\
\hline Nile crocodile Crocodylus niloticus & 0 & 0 & 0 & 3 & 0 & 3 & 3 & 0 & 3 \\
\hline Tortoise (Chelonian spp.) & 0 & 0 & 0 & 1 & 1 & 2 & 1 & 1 & 2 \\
\hline
\end{tabular}

\section{Results}

The market survey: species, volumes and values

The estimated numbers of animals of at least 20 species killed and traded during the study year are presented in Table 1. The total number of animals killed is $>1,100$, whereas the estimated number of whole animals traded locally is c. 300. The difference between these estimates represents the minimum amount of meat transported to non-local markets and consumed in actors' own households. At least $59 \%$ of the total volume of bushmeat bypasses local markets this way. The most commonly killed species were hippopotamus Hippopotamus amphibius (categorized as Vulnerable on the IUCN Red List), buffalo and puku. African elephant Loxodonta africana (Vulnerable) and Abbott's duiker Cephalophus spadix (Endangered) were also sold in the market. In terms of weight we estimate that hunting produced c. $370,000 \mathrm{~kg}$ meat annually, of which $150,000 \mathrm{~kg}$ was traded in the local markets. Most packages of meat $(60 \%)$ were fresh. Meat from larger animals (hippopotamus, buffalo and elephant) was more often dried. The minimum value of the local bushmeat trade (i.e. excluding own-consumption and non-local trade) amounted to c. USD 70,000 ( $\sum$ [number of packages $\times$ species-specific package price]). Considering instead the total number of animals killed, the estimated annual gross turnover was USD 210,000, with USD 40,000 ( $\sum$ [number of animals $x$ mean whole-animal species-specific price]) and 170,000 $\left(\sum\right.$ number of packages per animal $\times$ number of animals $\times$ mean species-specific package price]) accruing to hunters and traders, respectively (retailer income included in trader figure). This amount is supplemented by income from more valuable animal products traded through other value chains (e.g. ivory, hippopotamus teeth, crocodile skin and fat, and lion oil).

\section{Structure of the value chain}

An overview of the organization of actor groups in the value chain is presented in Fig. 2. The general downstream flow of activities undertaken by the three actor groups is as follows: wildlife is killed, initially processed (larger species are chopped/divided into manageable portions), possibly upgraded (dried or smoked to facilitate long-distance transportation), transported to villages (or directly to non-local markets), cut into smaller pieces (i.e. packages, final processing), and sold in the villages. The functions performed by actor groups are limited and may overlap: (1) hunters kill, do the initial processing and may upgrade the meat; (2) traders may also upgrade the meat, and they transport it, do the final processing and sell to end consumers and transport intermediaries; and (3) retailers sell the meat, primarily to end consumers. Hunters in Udzungwa Scarp Forest Reserve are primarily farmers, with agricultural fields adjacent to the forest. They mostly use traps and sell the meat locally 


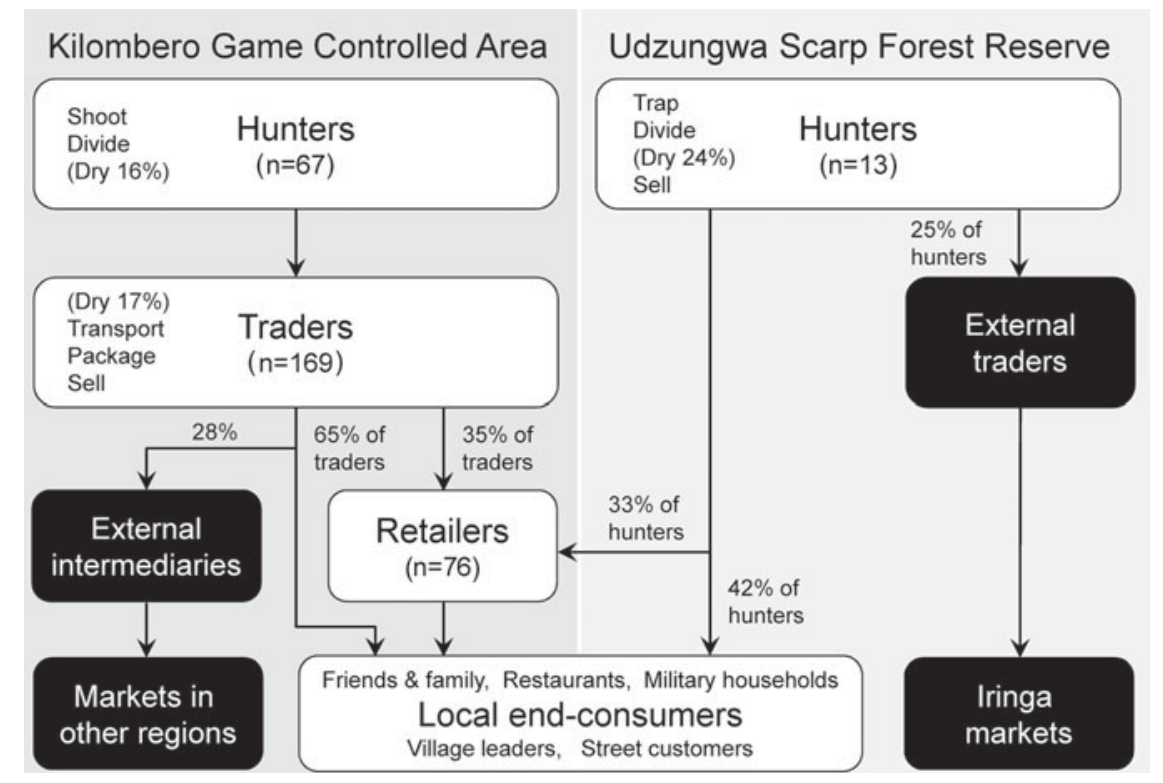

FIg. 2 Overview of the Kilombero Valley bushmeat value chain, differentiating between trade originating from the Kilombero Game Controlled Area and from the Udzungwa Scarp Forest Reserve. Black boxes represent non-local nodes of the value chain not included in the study. themselves or to traders from the Iringa side of the Reserve. Hunters in Kilombero Game Controlled Area use firearms almost exclusively and may spend extended periods in the bush, shooting several animals to supply many traders. They are often accompanied by assistants who help butcher and transport the meat to bush camps where traders are waiting. Traders are essentially one-person businesses and operate by accompanying hunters to bush camps or waiting in the village for phone calls from successful hunters to negotiate prices and quantities before heading to the kill site. Some meat is dried. This is time-consuming and increases the likelihood of apprehension but reduces perishability, thus facilitating long-distance transport. Drying is done by hunters ( $16 \%$ of trips $\pm 4.495 \% \mathrm{CI}$ ) when animal or distance is large and demand low, or by traders ( $17 \%$ of trips $\pm 4.295 \% \mathrm{CI}$ ) on request from so-called special customers (i.e. non-local traders or external transport intermediaries) to coincide with them travelling through the village. Transport to villages is by bicycle at night. Meat is then cut into packages and sold by traders (65\%) from their houses or to established customers that include military households, village leaders and elites, family and friends, restaurants and soup kitchens, and non-local traders. The remaining traders $(35 \%)$ hire retailers to sell the meat by commission (typically one package of meat for their own use and TZS $100-500$ for each package sold for TZS 3,000). Retailers sell to customers on the street but may also have their own established customers. No traders or retailers own or use refrigerators or non-home storage facilities. Meat for non-local markets is traded mainly in larger clumps (mandas) sold by hunters in the Udzungwa Scarp Forest Reserve to traders coming on foot from villages on the Iringa side of the Reserve, and by traders in the three villages to external transport intermediaries (i.e. the special customers), including bus and lorry drivers and train passengers. The meat is transported to nearby towns, including Mafinga and Ifakara, hidden within bags of agricultural products such as rice and vegetables, or in buckets of fish. It also reaches Mbeya and Tonduma in Mbeya Region, from where some may cross the border into Zambia and Malawi. Eastwards the meat reaches Dar es Salaam. Bribes of TZS 40,000-50,000 (2011 prices) to security guards on trains and to traffic police ensure safe passage if the meat is discovered.

\section{Governance along the value chain}

We did not observe actors attempting to limit or control the actions of others. Rather, collaboration appeared necessary to disperse costs and risk when buying the large amounts of meat produced by some species. Trust established through long-term relations was a prerequisite for the credit arrangements that characterized many transactions. Access to firearms and a network of trusted traders and customers constituted entry barriers for hunters. Most hunters rented firearms from retired military staff and foresters (TZS 13,000-26,000 per trip; 2011 prices) and obtained ammunition from military staff or local shop owners. Renting out a firearm requires trust that the hunter is able to avoid apprehension and confiscation of the firearm (through paying a sufficient bribe). For traders the main entry barrier was financial capital, either cash or credit. Approximately $37 \%$ of traders always bought meat from hunters on credit. Retailers were hired by traders as casual labourers. They had no personal outlays, were not expected to compensate the trader if meat was confiscated, and therefore assumed less financial risk.

Approximately $30 \%$ of respondents had been apprehended hunting or trading bushmeat one or more 


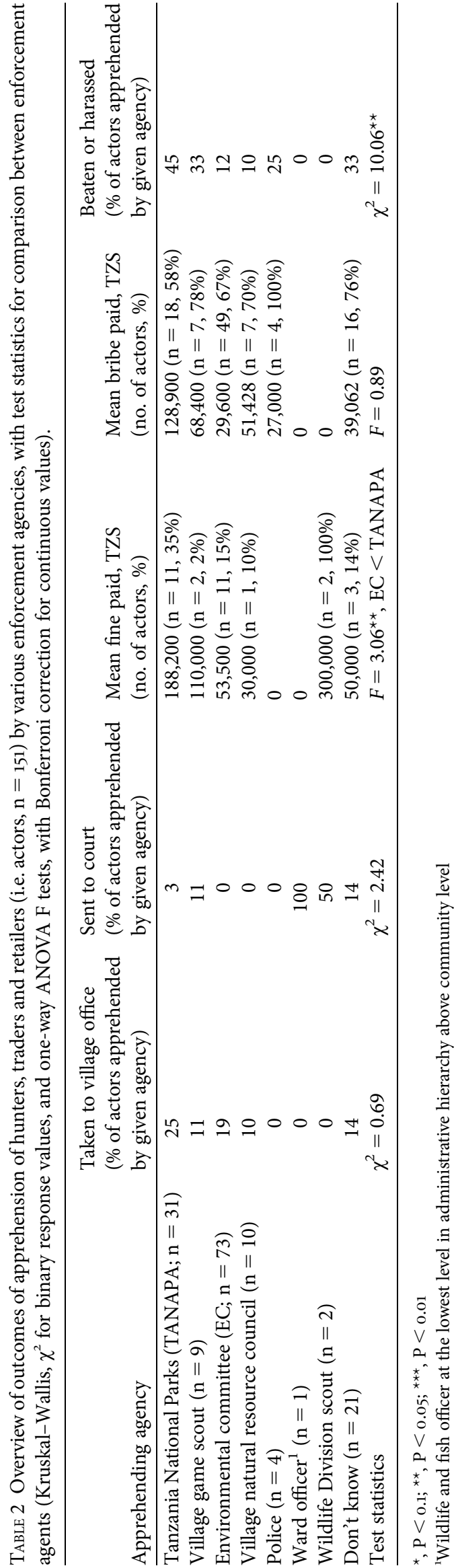

times. In many cases offenders were beaten and/or humiliated (Table 2). Punishments included being forced to eat raw bushmeat, being beaten unconscious and having trigger fingers broken. The anti-poaching patrols of former hunting block owners in Kilombero Game Controlled Area (as of November 2011 the blocks were not allocated) were particularly violent (MRN, unpubl. data). To reduce the risk of apprehension actors carried mobile phones (to receive early warning when patrols arrived in the area) and cash for payment of bribes. Most arrests resulted in payment of a bribe (66\% of cases) and only in a minority of cases was a fine paid (19\%). Bribes were highly variable but, as expected, significantly lower than fines $(t=3.06, \mathrm{P}<0.01)$. Approximately $29 \%$ of respondents reported bribing preemptively village council, environmental committee and village natural resource council members as well as police officers, with bushmeat, beer or cash, to avoid apprehension. Hunters paid significantly higher bribes (although not higher fines; Table 3 ) if caught, perhaps to avoid confiscation of firearms. Working in the villages, retailers had the highest likelihood of being apprehended but paid the lowest bribes if caught. The high mean fines paid by this group may be attributable to the low sample size of individuals actually paying a fine.

\section{Distribution of profit}

Hunters in Kilombero Game Controlled Area on average obtained significantly higher profits per day and month than traders and retailers (Table 3 ), suggesting that they had greater bargaining power. Hunters also spent almost twice as many days hunting as traders spent trading. It appears that those who obtained a high profit waited longer before making the next trip. There were no significant differences in monthly profits between traders and retailers, although the former earned significantly higher profits per day. This is probably attributable to the traders' lower level of activity. Traders who did not employ retailers had significantly higher profits on a monthly basis only $(t=2.50, \mathrm{P}<0.05)$. Purchasing the meat meant that traders incurred significantly higher variable costs per day than hunters $(t=2.98$, $\mathrm{P}<0.01)$; they also had a higher risk of being apprehended, which together may explain the high level of dependence on credit arrangements with the hunters. There was no significant difference in profit between traders buying by cash or credit $(t=0.90, \mathrm{P}>0.1)$. This may reflect that mostly larger animals were bought on credit.

Comparing the income composition of the three groups (Table 3) reveals that a significantly higher proportion of the income of traders and retailers originates from casual labour $(F=3.63, \mathrm{P}<0.05)$, which is compatible with waiting in the village for calls from hunters and returning traders, respectively. Hunters also have significantly less invested in domestic animals than traders $(F=5.98, \mathrm{P}<0.01)$, and less 
TABLE 3 Comparison of demographic, socio-economic and trade variables between hunters, traders and retailers in the Kilombero Valley local bushmeat value chain. Income from bushmeat is not included under income share.

\begin{tabular}{|c|c|c|c|}
\hline Variables $^{*}$ & Hunter $(\mathrm{n}=80)$ & Trader $(\mathrm{n}=169)$ & Retailer $(\mathrm{n}=76)$ \\
\hline \multicolumn{4}{|l|}{ Demographics } \\
\hline Mean age $\pm S D$ (years) & $41.2 \pm 7.9$ & $36.3 \pm 8.9$ & $36.4 \pm 8.1$ \\
\hline $\mathrm{AEU} \pm \mathrm{SD}$ & $3.9 \pm 1.4$ & $3.4 \pm 1.6$ & $3.2 \pm 1.5$ \\
\hline Born locally (\%) & 55 & 57 & 58 \\
\hline Married (\%) & 96 & 79 & 87 \\
\hline Mean no. of years of education per household \pm SD & $6.7 \pm 1.5$ & $7.2 \pm 1.6$ & $7.2 \pm 0.9$ \\
\hline \multicolumn{4}{|l|}{ Income share } \\
\hline Annual salary income/AEU (\%) & 3.38 & 7.68 & 9.08 \\
\hline Annual business income/AEU (\%) & 10.65 & 7.13 & 12.97 \\
\hline Annual agricultural income/AEU (\%) & 31.94 & 34.12 & 39.25 \\
\hline Annual income from domestic animals/AEU (\%) & 4.94 & 9.43 & 11.76 \\
\hline Annual income from non-timber forest products/AEU (\%) & 46.97 & 40.59 & 25.90 \\
\hline Annual income from rent/AEU (\%) & 1.92 & 0.83 & 0.64 \\
\hline Other income/AEU (\%) & 0.19 & 0.23 & 0.41 \\
\hline \multicolumn{4}{|l|}{ Assets } \\
\hline Mean value of household assets \pm SD (TZS) & $54,950 \pm 40,739$ & $62,647 \pm 43,001$ & $55,571 \pm 48,254$ \\
\hline Mean area of cultivated land \pm SD (acre) & $0.81 \pm 0.39$ & $0.93 \pm 0.55$ & $0.99 \pm 0.60$ \\
\hline Mean value of domestic animals/AEU \pm SD (TZS) & $22,965 \pm 27,109$ & $44,662 \pm 50,504$ & $37,801 \pm 51,627$ \\
\hline Own house & $80 \%$ & $82 \%$ & $82 \%$ \\
\hline \multicolumn{4}{|l|}{ Bushmeat trade } \\
\hline Mean no. effort days per year $\pm S D$ & $121 \pm 59$ & $64 \pm 48$ & $80 \pm 54$ \\
\hline Mean profit per day \pm SD (TZS) & $44,097 \pm 67,855$ & $30,573 \pm 35,293$ & $10,093 \pm 7,047$ \\
\hline Mean profit per month \pm SD (TZS) & $194,144 \pm 176,739$ & $89,298 \pm 80,516$ & $66,779 \pm 81,883$ \\
\hline Mean cost per day $\pm \mathrm{SD}(\mathrm{TZS})$ & $22,774 \pm 55,572$ & $35,127 \pm 34,790$ & $69,620 \pm 37,926$ \\
\hline Mean cost per month \pm SD (TZS) & $82,763 \pm 87,955$ & $103,820 \pm 106,624$ & $289,133 \pm 86,017$ \\
\hline Mean likelihood of apprehension per day & 0.00119805 & 0.00179185 & 0.00238892 \\
\hline Mean value of bribes \& confiscated material $\pm \mathrm{SD}$ (TZS) & $87,333 \pm 97,424$ & $43,050 \pm 43,669$ & $17,652 \pm 17,523$ \\
\hline Mean value of fines \& confiscated material $\pm \mathrm{SD}$ (TZS) & $88,750 \pm 96,427$ & $110,938 \pm 91,145$ & $184,600 \pm 399,929$ \\
\hline
\end{tabular}

${ }^{\star} \mathrm{AEU}$, Adult equivalent unit

income from domestic animals than both traders and retailers $(F=3.50, \mathrm{P}<0.05)$ but higher income from land rent $(F=3.54, \mathrm{P}<0.05)$, which suggests they are focusing on hunting rather than agriculture and domestic animal rearing. Finally, hunters are significantly older $(F=9.76$, $\mathrm{P}<0.01)$, more likely to be married $\left(\chi^{2}=4.47, \mathrm{P}<0.1\right)$, and have larger households $(F=4.48, \mathrm{P}<0.05)$ and a lower level of education $(F=3.63, \mathrm{P}<0.05)$.

\section{Discussion}

Validity of findings on the scale of the market

The two conservative methods applied to estimate the amount of bushmeat produced by hunters in the Kilombero Valley yield results comparable to the findings of related studies. For example, illegal hunting in Serengeti National Park and surrounding protected areas (c. 6,600 $\mathrm{km}^{2}$ ) has been estimated to produce 11,950 tonnes of meat annually, of which a third may be traded for $>$ USD 1 million (Hofer et al., 1996; Loibooki et al., 2002), and estimates indicate that $130,500 \mathrm{~kg}$ of bushmeat was produced, using traps, by 96 hunters arrested in the Serengeti (Holmern et al., 2002).
These and other results (Olupot et al., 2009) support our estimates of the volume and value of the bushmeat trade in the Kilombero Valley. However, difficulties in identifying species and problems relating packages of meat to whole animals introduce uncertainty in estimates. Some smaller species may never or only rarely enter the trade, and therefore for these species the catch is underestimated. The fact that the trade occurs undercover in contravention of Tanzania's wildlife laws makes information on volumes and values sensitive and suggests that all estimates should be considered conservative. In particular it should be noted that values do not include income from complementary products (such as ivory) or consider increases in value along the non-local segments of the value chain.

\section{Structure and operation of the value chain}

We found a short local value chain in the Kilombero Valley bushmeat trade, with three well-defined actor groups, each with a specific set of functions. Information and products flow freely between these groups despite the existence of credit arrangements that can tie or subjugate some groups to others (Brooks et al., 2010). No evidence of exploitative 
patron-client relationships was observed, as has been reported from communities adjacent to Garamba National Park in the Democratic Republic of Congo, where soldiers and traditional authorities provided protection against fines and access to credit and firearms, and where changes in these arrangements were fundamental determinants of hunting intensity and catch of threatened species (de Merode \& Cowlishaw, 2006). In the Kilombero Valley, interactions with authorities and enforcement agents had the character of illicit taxation more than implementation of wildlife regulations, with rent-seeking enforcement agents using violence to determine the maximum amount that the offender was able to pay as a bribe. Respondents claimed that offenders had died at the hands of government enforcement agents and the anti-poaching patrols of previous hunting block owners. This suggests a sample selection bias, given the absence of the testimonies of those who did not survive such encounters.

Hunters appeared to have the highest level of bargaining power, earning higher daily profit than other actor groups. This is comparable to the situation in the Takoradi market in Ghana, where hunters captured the highest proportion of the final sale price (Cowlishaw et al., 2005). There were twice as many traders as hunters and they spent half as much time in the trade, making less profit and having lower total annual income. This suggests a market limited by supply, with competition between traders. A more common scenario appears to be competition between primary producers for traders, weakening the position of producers relative to buyers, particularly where the product is perishable as in the case of bushmeat (Morra et al., 2009). This often enables traders to control the trade (Brooks et al., 2010). The hunters' favourable bargaining position was probably enhanced by entry barriers, diminishing resources, and the free flow of price information through mobile phones. However, hunters carried considerable financial risk by extending credit to traders. The role of extending credit is normally fulfilled by traders (Belcher \& Schreckenberg, 2007). Retailers, having the lowest bargaining power, resorted to reducing the size of packages without the traders' knowledge, to increase their own profits.

\section{Limitations and drivers of the trade}

All actor groups earned supernormal profits (i.e. above the level of the closest alternative occupation). In comparison, the salary for casual labour was c. TZS 3,000-5,000 per day and net income from small-scale business was TZS 3,000-7,000 per day. Available information from Tanzania is sparse but studies in the Serengeti indicate an annual income from hunting of USD 65 per hunter (equivalent to TZS 45,500 at 1999 exchange rates), or USD 88 (c. TZS 144,000) at 2011 prices (Holmern et al., 2002). Our results indicate considerably higher income from hunting and trading bushmeat (Table 3), underlining the commercial nature of hunting in the Kilombero Valley. It is not uncommon for bushmeat hunting to generate substantial income (Tieguhong \& Zwolinski, 2009) but given the open-access situation in the study area normal profits would be expected. As the number of hunters increases this usually drives down profits and eventually discourages additional hunters from starting because they could earn the same in other available occupations. As the opportunity cost of hunting is low this zero-profit equilibrium would probably occur at high effort, resulting in low wildlife population densities (MilnerGulland, 2001). The supernormal profits observed here indicate that entry barriers and risks involved in trading bushmeat limit the number of hunters at a level well above the zero-profit equilibrium. Apart from wildlife densities, access to firearms appeared to be the main entry barrier limiting the bushmeat trade in the Kilombero Valley. The cost of hunting equipment has also been considered a limiting factor to the entry of hunters in other locations (Coad et al., 2010; Godoy et al., 2010). Knowledge and experience are also required to perform successfully in the bushmeat trade and hunters and traders must be able to negotiate prices under variable conditions of supply and demand (Mendelson et al., 2003), whereas the terms of retailers' involvement constitute less of an entry barrier (i.e. no investment and low skill).

\section{Conservation implications}

Although the entry barriers appear to facilitate equilibrium above the zero-profit level, the hunting effort appears to exceed sustainable harvest levels. Aerial surveys of Kilombero Game Controlled Area conducted in 1991 and 2009 (TAWIRI, 2009) indicate significant declines of buffalo (from $35,301 \pm$ SE 9,673 to $1,462 \pm$ SE 374), hippopotamus (from $5,413 \pm \mathrm{SE} 1,705$ to $514 \pm \mathrm{SE} 136$ ), warthog Phacochoerus africanus (from 1,291 \pm SE 272 to $290 \pm$ SE 88) and non-significant declines of puku (from $36,569 \pm$ SE 13,733 to $18,161 \pm$ SE 2,076) and elephant (from $1,848 \pm$ SE 512 to $1,535 \pm \mathrm{SE} 442$ ). There is no local institution to organize hunters and regulate hunting, and because hunting is illegal existing institutions do not have a mandate to manage exploitation for sustainable use. However, under Tanzania's Wildlife Conservation Act (URT, 2008) Wildlife Management Areas may be established, and the fact that the hunting blocks in Kilombero Game Controlled Area are currently unallocated provides an opportunity for decentralizing wildlife management rights and responsibilities to local communities, enabling them to coordinate and establish control of access. Devolvement of ownership rights is often considered essential because people will only conserve resources for the future if they are sure that they will benefit from restraints for long-term sustainability, and related arrangements have led to recovery of depleted wildlife populations 
elsewhere in Tanzania (Nielsen \& Treue, 2012). The new institution should focus on developing agreements between hunters to regulate extraction (including by redirecting hunting efforts towards species that can sustain hunting); establishing means to exclude outsiders (with assistance from enforcement agencies); and mechanisms for socially acceptable distribution of benefits. Challenges include resistance from vested interests in rent-seeking opportunities (including in hunting block allocations); prioritization between local livelihoods and conservation; and local resentment towards enforcement agents and authorities, and concerns that rights and revenues may be subsequently re-centralized.

Illegal bushmeat trade is a threat to the conservation of biodiversity in many parts of Africa. In East Africa lack of information about value chains constrains effective regulation of the bushmeat trade. Our findings show that bushmeat trade in the Kilombero Valley is large-scale, both in terms of volume and value, and includes species on the IUCN Red List. The trade flows freely between hunters, traders and retailers and we found no evidence of patronclient relationships influencing the trade. However, entry barriers, in particular access to firearms, curb supply and allow actors to realize supernormal profits. There are no institutions to restrict and coordinate the trade, which occurs in a context of weak enforcement and violent rentseeking by enforcement agents. This has created widespread resentment in local communities. Hunting is therefore open-access and has resulted in the decline of several wildlife populations. The most promising approach to halt current declines in wildlife populations appears to be through decentralized wildlife management. By devolving ownership and management rights and securing a fair distribution of benefits, incentives could be generated for communities to regulate access to wildlife. This should be complemented by interventions targeted at limiting the availability of firearms (e.g. through voluntary handing over of firearms, with financial compensation equivalent to the value of the weapon).

\section{Acknowledgements}

We are grateful to the bushmeat hunters and traders in the Kilombero Valley for entrusting Martin R. Nielsen with information about their activities. The Centre for Macro Ecology, Evolution and Climate at the University of Copenhagen and the Danish National Research Foundation provided funding.

\section{References}

Belcher, B. \& Schreckenberg, K. (2007) Commercialisation of non-timber forest products: a reality check. Development Policy Review, 25, 355-377.
Bennett, E.L., Blencowe, E., Brandon, K., Brown, D., Burn, R.W., Cowlishaw, D. et al. (2007) Hunting for consensus: reconciling bushmeat harvest, conservation and development policy in West and Central Africa. Conservation Biology, 21, 884-887.

Bonnington, C., Steer, M.D., Lamontagne-Godwin, J., Owen, N. \& Grainger, M. (2010) Evidence for local declines in Tanzania's puku antelope (Kobus vardoni Livingstone, 1857) population between 1999 and 2003. African Journal of Ecology, 48, 1139-1142.

Brooks, S.E., Kebede, B., Allison, E.H. \& Reynolds, J.D. (2010) The balance of power in rural marketing networks: a case study of snake trading in Cambodia. The Journal of Development Studies, 46, 1003-1025.

Cavendish, W. (2002) Quantitative methods for estimating the economic value of resource use to rural households. In Uncovering the Hidden Harvest: Valuation Methods for Woodland and Forest Resources (eds B. Campbell \& M. Luckert), pp. 17-65. Earthscan, Abingdon, UK.

Coad, L., Abernethy, K., Balmford, A., Manica, A., Airey, L. \& Milner-Gulland, E.J. (2010) Distribution and use of income from bushmeat in a rural village, central Gabon. Conservation Biology, 24, 1510-1518.

Cowlishaw, G., Mendelson, S. \& Rowcliffe, M. (2005) Structure and operation of a bushmeat commodity chain in southwestern Ghana. Conservation Biology, 19, 139-149.

De Merode, E. \& Cowlishaw, G. (2006) Species protection, the changing informal economy, and the politics of access to the bushmeat trade in the Democratic Republic of Congo. Conservation Biology, 20, 1262-1271.

Ellis, F. (1992) Agricultural Policies in Developing Countries. Cambridge University Press, Cambridge, UK.

Fa, J.E., Albrechtsen, L., Johnson, P.J. \& Macdonald, D.W. (2009) Linkages between household wealth, bushmeat and other animal protein consumption are not invariant: evidence from Rio Muni, Equatorial Guinea. Animal Conservation, 12, 599-610.

FA, J.E. \& Brown, D. (2009) Impacts of hunting on mammals in African tropical moist forests: a review and synthesis. Mammal Review, 39, 231-264.

Fa, J.E., Currie, D. \& Meeuwig, J. (2003) Bushmeat and food security in the Congo Basin: linkages between wildlife and people's future. Environmental Conservation, 30, 71-78.

FA, J.E. \& PURVIS, A. (1997) Body size, diet and population density in afrotropical forest mammals: a comparison with neotropical species. Journal of Animal Ecology, 66, 98-112.

Godoy, R., Undurraga, E.A., Wilkie, D., Reyes-García, V., Huanca, T., Leonard, W.R. et al. (2010) The effect of wealth and real income on wildlife consumption among native Amazonians in Bolivia: estimates of annual trends with longitudinal household data (2002-2006). Animal Conservation, 13, 265-274.

Hill, K. \& HAWKes, K. (1983) Neotropical hunting among the Ache of Paraguay. In Traditional Peoples and Biodiversity Conservation in Large Tropical Landscapes (eds K.H. Redford \& J.A. Mansour), pp. 159-196. The Nature Conservancy, Arlington, USA.

Hofer, H., Campbell, K.L.I., East, M.L. \& Huish, S.A. (1996) The impact of game meat hunting on target and non-target species in the Serengeti. In The Exploitation of Mammal Populations (eds V.J. Taylor \& N. Dunstone), pp. 117-146. Chapman \& Hall, London, UK.

Holmern, T., Røskaft, E., Mbaruka, J., Mkama, S.Y. \& Muya, J. (2002) Uneconomical game cropping in a community-based conservation project outside the Serengeti National Park, Tanzania. Oryx, 36, 364-372.

IUCN SSC Antelope Specialist Group (2009) One Fourth of Antelope Species are Threatened with Extinction in the World. 
Http://cmsdata.iucn.org/downloads/antelope_report.pdf [accessed 10 July 2012].

Jenkins, R.K.B., Corti, G.R., Fanning, E. \& Roettcher, K. (2002) Management implications of antelope habitat use in the Kilombero Valley, Tanzania. Oryx, 36, 161-169.

Kingdon, J. (1997) The Kingdon Field Guide to African Mammals. Academic Press Limited, London, UK.

Loibooki, M., Hofer, H., Campbell, K.L.I. \& East, M.L. (2002) Bushmeat hunting by communities adjacent to the Serengeti National Park, Tanzania: the importance of livestock ownership and alternative sources of protein and income. Environmental Conservation, 29, 391-398.

Mendelson, S., Cowlishaw, G. \& Rowcliffe, J.M. (2003) Anatomy of a bushmeat commodity chain in Takoradi, Ghana. Journal of Peasant Studies, 31, 73-100.

Milner-Gulland, E.J. (2001) Assessing sustainability of hunting: insights from bioeconomic modelling. In Hunting and Bushmeat Utilization in the African Rain Forest: Perspectives Toward a Blueprint for Conservation Action (eds M.I. Bakarr, G.A.B. da Fonseca, R. Mittermeier, A.B. Rylands \& K.W. Painemilla), pp. 113-151. Conservation International, Washington, DC, USA.

Milner-Gulland, E.J., Bennett, E.L. \& The SBC 2000 Annual Meeting Wild Meat Group (2003) Wild meat: the bigger picture. Trends in Ecology \& Evolution, 18, 351-357.

Mitchell, J. \& Coles, C. (eds) (2011) Markets and Rural Poverty: Upgrading in Value Chains. Earthscan, London, UK.

Morra, W., Hearn, G. \& Buck, A.J. (2009) The market for bushmeat: Colobus satanas on Bioko Island. Ecological Economics, $68,2619-2626$.

Nielsen, M.R., Jacobsen, J.B. \& Thorsen, B.J. (2014) Factors determining the choice of hunting and trading bushmeat in the Kilombero Valley, Tanzania. Conservation Biology, 28, 382-391.

Nielsen, M.R. \& Treue, T. (2012) Hunting for the benefits of joint forest management in the Eastern Afromontane Biodiversity Hotspot: effects on bushmeat hunters and wildlife in the Udzungwa Mountains. World Development, 40, 1224-1239.

Olupot, W., McNeilage, A.J. \& Plumptre, A.J. (2009) An Analysis of Socioeconomics of Bushmeat Hunting at Major Hunting Sites in Uganda. Wildlife Conservation Society, Kampala, Uganda.

PARKER, I.S.C. \& MARTin, E.B. (1982) How many elephants are killed for the ivory trade? Oryx, 16, 235-239.

Patton, M. (1990) Qualitative Research \& Evaluation Methods. Sage Publications, Newbury Park, USA.
Poknrel, D.M. \& Thapa, G.B. (2007) Are marketing intermediaries exploiting mountain farmers in Nepal? A study based on market price, marketing margin and income distribution analyses. Agricultural Systems, 94, 151-164.

Robinson, J.G. \& Bennett, E.L. (200o) Carrying capacity limits to sustainable hunting in tropical forests. In Hunting for Sustainability in Tropical Forests (eds J.G. Robinson \& E.L. Bennett), pp. 13-30. Columbia University Press, New York, USA.

Rowcliffe, J.M., Milner-Gulland, E.J. \& Cowlishaw, G. (2005) Do bushmeat consumers have other fish to fry? Trends in Ecology \& Evolution, 20, 274-276.

Stoner, S.S. \& Pervushina, N. (2013) Reduced to Skin and Bone Revisited: An Updated Analysis of Tiger Seizures from 12 Tiger Range Countries (2000-2012). TRAFFIC, Kuala Lumpur, Malaysia.

TAWIRI (2009) Kilombero Ramsar Site Project, KVRSP: Wet Season 2009 Aerial Census in the Kilombero Valley Floodplains Ramsar Site. Tanzania Wildlife Research Institute in collaboration with Tanzanía National Parks and Wildlife Division, Arusha, Tanzania.

The World Bank (2012) Africa Development Indicators. Http://data. worldbank.org/data-catalog/africa-development-indicators [accessed 10 July 2012].

Tieguhong, J.C. \& Zwolinski, T.J. (2009). Supplies of bushmeat for livelihoods in logging towns in the Congo basin. Journal of Horticulture and Forestry, 1, 65-80.

URT (United Republic of Tanzania) (2008) Wildlife Conservation Act (no. 5 of 2009). Ministry of Natural Resources and Tourism, Dar es Salaam, Tanzania.

\section{Biographical sketches}

Martin R. Nielsen has been studying hunting since 2000, ranging from illegal bushmeat hunting in Africa to traditional whaling in Greenland. His research focuses on the human dimensions of wildlife management and the socioeconomic and cultural impacts of management policies. HeNRIK MeILBy's research interests lie in assessment and monitoring of living natural resources, including vegetation and wildlife, resource management, economics of sustainable resource use, and the interaction between nature and society. CARSTEN SMITH-HALL's research is focused on forest-livelihood relationships, including the role of forests in preventing and reducing poverty, forests and human health, and commercial utilization of biodiversity, including value chains. 